\title{
Rekomendasi Adaptasi dan Mitigasi Bencana Banjir di Kawasan Rawan Bencana (KRB) Banjir Kota Bima
}

\author{
Recommendations for Adaptation and Mitigation of Flood Disaster \\ in Disaster Prone Areas of Bima City
}

\author{
Rizki Kirana Yuniartanti ${ }^{1 *}$ \\ ${ }^{1}$ Kementerian Agraria dan Tata Ruang, Jalan Raden Patah 1 Nomor 1, Jakarta Selatan 12014, Indonesia; \\ *Penulis korespondensi. e-mail: rizki.kirana@gmail.com \\ (Diterima: 18 Maret 2018; Disetujui: 29 Juni 2018)
}

\begin{abstract}
Flood disaster occurred on December 21, 2016, December 23, 2016, and January 2, 2017 in Bima city area, covering Mpunda district, Rasanae Timur district, Asakota district, Rasanae Barat district, and Raba district. The urban area is the most affected area of flash flood, mainly residential areas that are located more than 50 meters from the flood plains, with flood heights ranging from 1 to 4 meters. The main factor that caused flood disaster is high rainfall. In addition to the hydrometeorological factor, flood in Bima city was caused by various factors, including its location at a basin area, flood plains that are utilized for settlements nowadays, silting downstreams, poor management of drainage systems, reduced vegetation-cover in the upstream, and narrowing of river bodies. Looking at the problems and challenges of the hydrometeorological disaster, this research aims to recommend adaptation and mitigation for flood disaster and space utilization conversion in disaster prone areas of Bima city. Analytical methods used in this research includes participatory mapping to delineate the flood affected area, HEC-RAS and HECGEORAS to map and model flood hazards, and quantitative descriptive to describe data and information. Output of this research are adaptation and mitigation recommendations based on the mapping of flood hazard areas and the modeling of flood disaster prone areas.
\end{abstract}

Keywords: adaptation, flood, mitigation

\begin{abstract}
ABSTRAK
Bencana banjir bandang terjadi pada tanggal 21 Desember 2016, 23 Desember 2016 dan 2 Januari 2017 di Kota Bima, Provinsi Nusa Tenggara Barat. Kawasan perkotaan menjadi kawasan paling terdampak banjir bandang, terutama kawasan permukiman yang berjarak lebih dari 50 meter dari sempadan sungai, dengan ketinggian genangan banjir bervariasi, berkisar 1 hingga 4 meter. Faktor utama penyebab banjir adalah curah hujan yang tinggi. Selain faktor hidrometeorologi, banjir di Bima disebabkan oleh berbagai faktor, diantaranya kawasan Kota Bima sebagai cekungan, hilangnya fungsi sempadan sungai yang saat ini banyak yang menjadi kawasan permukiman, pendangkalan pada bagian hilir sungai, sistem drainase perkotaan yang buruk, berkurangnya tutupan vegetasi pada bagian hulu, serta penyempitan badan sungai. Melihat permasalahan dan tantangan terhadap bencana hidrometeorologi yang semakin meningkat, maka kajian ini bertujuan untuk memberikan arahan rekomendasi adaptasi dan mitigasi di KRB Banjir Kota Bima. Metode analisis yang digunakan dalam penelitian ini adalah pemetaan partisipatif untuk mendelineasi kawasan terdampak banjir, pemetaan dan pemodelan bahaya banjir dengan HEC-RAS dan HEC-
\end{abstract}


GEORAS untuk menghasilkan simulasi debit dan juga deskriptif kuantitatif untuk mengulas data dan informasi dalam kajian ini. Kajian ini menghasilkan keluaran rekomendasi adaptasi dan mitigasi yang sesuai dengan pemetaan kawasan terdampak banjir dan pemodelan bahaya banjir.

Kata kunci: adaptasi, banjir, mitigasi

\section{PENDAHULUAN}

Indonesia merupakan daerah rawan bencana, karena letaknya berada di ring of fire (Soemabrata, et al., 2018), sehingga sangat berpotensi akan terjadinya bencana alam. Pada umumnya bencana alam di Indonesia meliputi bencana akibat faktor geologi (Arsyad \& Riadi, 2013) dan bencana akibat hidrometeorologi (Adi, 2013; Yanto, et al., 2017).

United Nations International Strategy for Disaster Reduction (UNISDR) menyatakan bahwa bencana hidrometeorologi semakin meningkat tiap tahunnya di negara-negara di Asia termasuk Indonesia. Curah hujan berskala normal hingga tinggi terjadi di beberapa wilayah Indonesia pada periode 2015 hingga 2016. Pada tahun 2016 curah hujan di bawah normal dan normal terjadi di wilayah Indonesia bagian tengah dan barat dan di atas normal untuk Indonesia bagian timur (Buletin Pemantauan Ketahanan Pangan Indonesia: Fokus Utama Cuaca Ekstrim, 2016).

Efek terbesar dari terganggunya siklus hidrometeorologi adalah bencana banjir. Berdasarkan Data dan Informasi Bencana Indonesia (BNPB, 2016), total kejadian banjir di Indonesia tahun 2012 hingga 2016 sebanyak 3,062 kejadian. Akhir tahun 2016, terjadi hujan dengan intensitas tinggi akibat adanya siklon tropis Yvette yang posisinya di Samudera Hindia Selatan Bali, sekitar $620 \mathrm{~km}$ sebelah selatan Denpasar dengan arah dan kecepatan gerak Utara Timur Laut. Adanya siklon tropis tersebut menyebabkan hujan ekstrim di beberapa wilayah di Nusa Tenggara Barat (NTB) di antaranya Bima dan Sumbawa.

Bencana banjir bandang di Bima terjadi pada tanggal 21 Desember 2016, 23 Desember 2016, dan 2 Januari 2017. Bencana banjir bandang mulai menerjang pada pukul 15.30 WITA di Kota Bima dengan ketinggian genangan 1 sampai dengan 4 meter. Wilayah terdampak di Kota Bima adalah Kecamatan Mpunda, Kecamatan Rasanae Timur, Kecamatan Asakota, Kecamatan Rasanae Barat, dan Kecamatan Raba. Kejadian banjir pada 23 Desember 2016 disebabkan peningkatan pertumbuhan awan yang meluas, sehingga menyebabkan hujan dengan intensitas tinggi di seluruh Kota Bima. Banjir menerjang Kota Bima sejak pukul 14.30 WITA. Di Kota Bima, banjir melanda lima wilayah kecamatan. Kejadian banjir berikutnya terjadi pada 2 Januari 2017, dengan dampak tidak separah banjir tanggal 21 Desember 2016 dan 23 Desember 2016.

Kawasan perkotaan menjadi kawasan paling terdampak banjir bandang tanggal 21 Desember 2016 dan 23 Desember 2016, terutama kawasan permukiman yang berjarak lebih dari 50 meter dari sempadan sungai, dengan ketinggian genangan banjir bervariasi, berkisar 1 sampai dengan 4 meter. Faktor utama penyebab banjir adalah curah hujan yang tinggi. Selain faktor hidrometeorologi, banjir di Bima disebabkan oleh berbagai faktor, di antaranya kawasan Kota Bima sebagai cekungan, hilangnya fungsi sempadan sungai yang saat ini banyak yang menjadi kawasan permukiman, pendangkalan pada bagian hilir sungai, sistem drainase perkotaan yang buruk, berkurangnya tutupan vegetasi pada bagian hulu, serta penyempitan badan sungai. (Hasil pengamatan Tim Kaji Cepat Kementerian ATR/BPN, 28 Desember 2017).

Dengan melihat permasalahan dan potensi bencana di Kota Bima, maka kajian ini bertujuan merumuskan rekomendasi adaptasi dan mitigasi sesuai pemetaan kawasan rawan bencana banjir dan pemodelan bahaya banjir. 


\section{METODOLOGI}

Kajian "Rekomendasi Adaptasi dan Mitigasi di Kawasan Rawan Bencana (KRB) Banjir Kota Bima" dilaksanakan pada tahun 2017. Dengan unit pengelolaan Daerah Aliran Sungai (DAS) Rontu dan unit administrasi Kota Bima seperti pada Gambar 1.

Dalam kajian ini memerlukan data primer dan sekunder yang didapatkan dari observasi lapangan maupun pengumpulan data dar Kementerian/Lembaga, Pemerintah Daerah Kota Bima, dan juga informasi dari masyarakat. Data primer dan sekunder yang didapatkan dari Kementerian/Lembaga dan Pemerintah Daerah Kota Bima berupa program kegiatan penanggulangan bencana, potensi bencana banjir, dan konsultasi terhadap pemodelan bahaya banjir. Informasi dari masyarakat berupa historis banjir di Kota Bima.

Observasi lapangan bertujuan untuk mengetahui historis dan wilayah terdampak banjir, berupa jejak banjir pada tahun 2016 hingga 2017, baik ketinggian genangan dan dampak yang ditimbulkan.

Pemodelan bahaya banjir Kota Bima menggunakan perangkat lunak HEC-RAS dan HEC-GEORAS, sehingga menghasilkan simulasi model banjir dalam kala ulang Q5, Q 25, Q50, dan Q100 beserta luasan genangannya. Pemetaan dan pemodelan ini menghasilkan estimasi dan ketinggian banjir pada kala ulang tertentu (Santosa, 2006). Pemodelan berbasis spasial dapat dilakukan dnegan Sistem Informasi Geografis (SIG) dengan menggunakan data Idigital Elevation Model (DEM) (Seniarwan et al., 2013). Data yang digunakan dalam pemetaan dan pemodelan bahaya banjir dibedakan menjadi 2, yaitu data kualitatif, untuk mengidentifikasi karakteristik fisik perkotaan dan data kuantitatif, untuk merepresentasikan penampang dan bantaran sungai.
Setelah dilakukan pemetaan kawasan terdampak dan pemodelan beserta analisis spasial proyeksi genangan, maka dapat ditentukan rekomendasi adaptasi dan mitigasi bencana banjir di KRB banjir Kota Bima.

Tahapan analisis dalam kajian ini meliputi:

1. Identifikasi karakterisitik wilayah Kota Bima beserta potensi dan masalah Kawasan Rawan Bencana (KRB) Bima

2. Inventarisasi teori dan konsep penataan ruang kawasan rawan bencana

3. Observasi lapangan dan pemetaan partisipatif kawasan terdampak

4. Pengumpulan data guna flood hazard mapping and modelling

5. Observasi lapangan kawasan hulu DAS untuk mengidentifikasi peruntukan lahan eksisting dan indikasi adanya alih fungsi lahan

6. Inventarisasi kegiatan dan program mitigasi struktural dan non struktural yang berasal dari Pemerintah Pusat maupun Pemerintah Daerah

7. Penyusunan peta kawasan terdampak dan pemodelan beserta analisis spasial proyeksi genangan

8. Rekomendasi adaptasi dan mitigasi di KRB banjir Kota Bima

Kajian ini juga mengacu pada kebijakan pada level pusat hingga daerah yang mengatur tata ruang dan penanggulangan bencana, antara lain:

1. Undang-Undang Nomor 24 Tahun 2007 tentang Penanggulangan Bencana

2. Undang-Undang Nomor 26 Tahun 2007 tentang Penataan Ruang

3. Peraturan Pemerintah Nomor 21 Tahun 2008 tentang Penyelenggaraan Penanggulangan Bencana

4. Peraturan Pemerintah Nomor 26 Tahun 2008 tentang Rencana Tata Ruang Wilayah Nasional (RTRWN)

5. Peraturan Pemerintah Nomor 15 Tahun 2010 tentang Penyelenggaraan Penataan Ruang 
6. Peraturan Daerah Provinsi Nusa tenggara Barat Nomor 3 Tahun 2010 tentang Rencana Tata Ruang Wilayah Provinsi Nusa Tenggara Barat Tahun 2009-2029
7. Peraturan Daerah Kota Bima Nomor 4 Tahun 2012 tentang Rencana Tata Ruang Wilayah Kota Bima Tahun 2011-2031

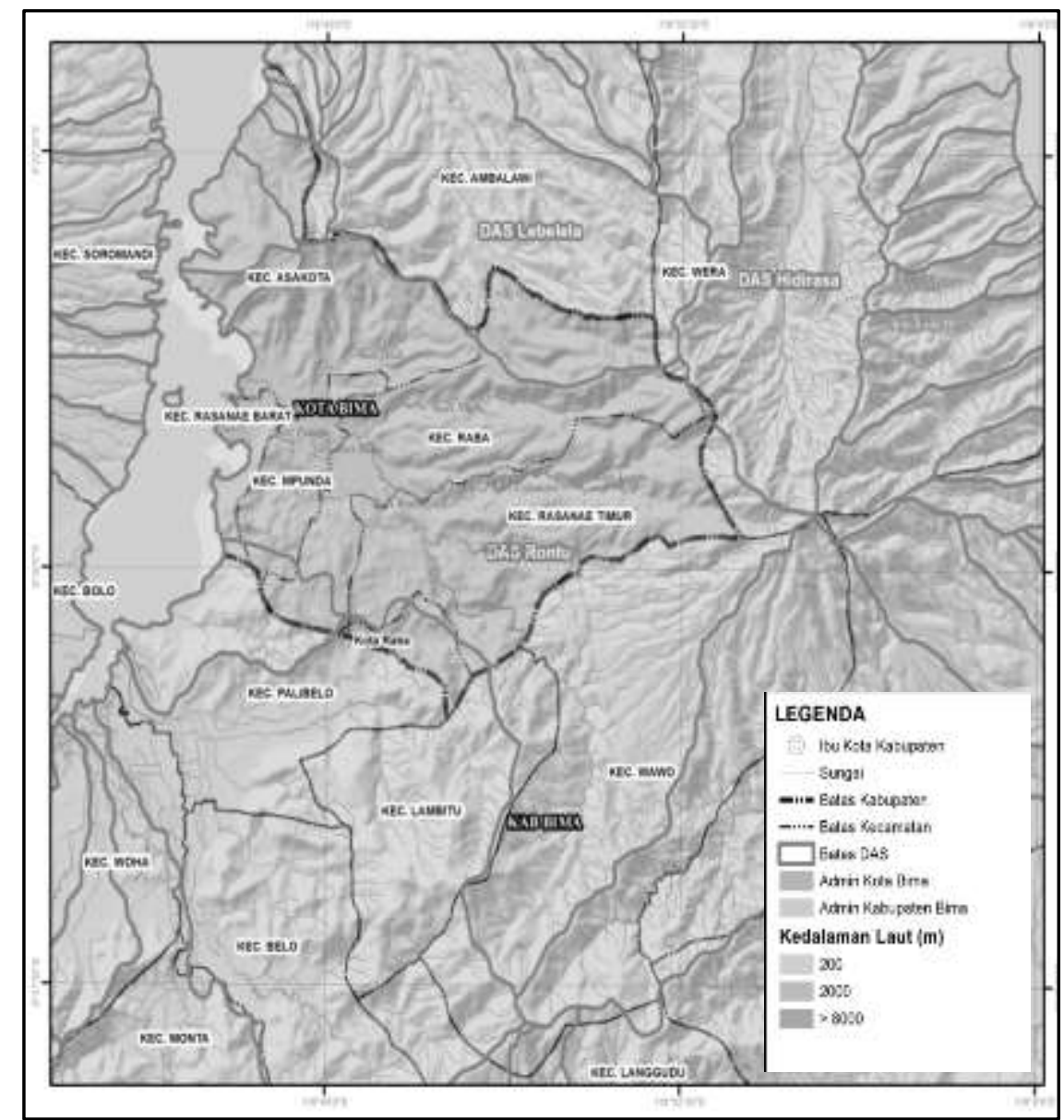

Gambar 1. Delineasi Daerah Aliran Sungai (DAS) di Kota Bima dan daerah sekitarnya Sumber: Hasil Analisis Penulis, 2017

\section{HASIL DAN PEMBAHASAN}

Pada bagian hasil dan pembahasan terdiri atas tiga sub bagian yaitu: A). Pemetaan Kawasan Terdampak Banjir; B). Pemetaan dan Pemodelan Bahaya Banjir; dan C). Rekomendasi Adaptasi dan Mitigasi dan juga Perubahan Peruntukkan Ruang di KRB Banjir Kota Bima.

\section{A. Pemetaan Kawasan Terdampak Banjir}

Berdasarkan hasil observasi lapangan untuk mengetahui historis banjir dan kawasan terdampak banjir dan juga hasil pemetaan partisipatif maka dapat diketahui kawasan terdampak banjir, ketinggian banjir, dan ketinggian genangan. Ketinggian genangan di kawasan terdampak banjir dapat dilihat pada tabel 1 .

Tabel 1. Klasifikasi Luasan dari Ketinggian Genangan pada Kawasan Terdampak Banjir di Kota Bima

\begin{tabular}{|c|c|c|c|}
\hline No. & $\begin{array}{l}\text { Tinggi } \\
\text { Meter }\end{array}$ & Genangan, & Luasan, Hektar \\
\hline 1. & $<0.5$ & & 245.67 \\
\hline 2. & $0.51-1.5$ & & 924.70 \\
\hline 3. & $1.51-2.5$ & & $1,170.91$ \\
\hline 4. & $2.51-3.5$ & & 225.42 \\
\hline 5. & $>3.51$ & & 6.03 \\
\hline Total & & & $2,578.13$ \\
\hline
\end{tabular}

Sumber: Hasil Analisis Penulis, 2017 
Dari tabel di atas, dapat diketahui bahwa tinggi genangan yang memiliki daerah terdampak paling luas adalah 1.51 hingga 2.50 m dengan luas 1,170.91 Ha. Sedangkan, tinggi genangan lebih dari $3.51 \mathrm{~m}$ menjadi yang luasannya paling kecil sebesar $6.03 \mathrm{Ha}$. Total luasan daerah terdampak seluas 2,578.13 Ha. Kecamatan yang memiliki ketinggian genangan kurang dari $0.5 \mathrm{~m}$ adalah Kecamatan Rasanae Timur dan Kecamatan Asakota.

Sedangkan, kecamatan yang memiliki ketinggian genangan lebih dari $3.51 \mathrm{~m}$ adalah Kecamatan Rasanae Barat dan Kecamatan Mpunda. Peta ketinggian genangan pada kawasan terdampak banjir di Kota Bima dapat dilihat pada Gambar 2.

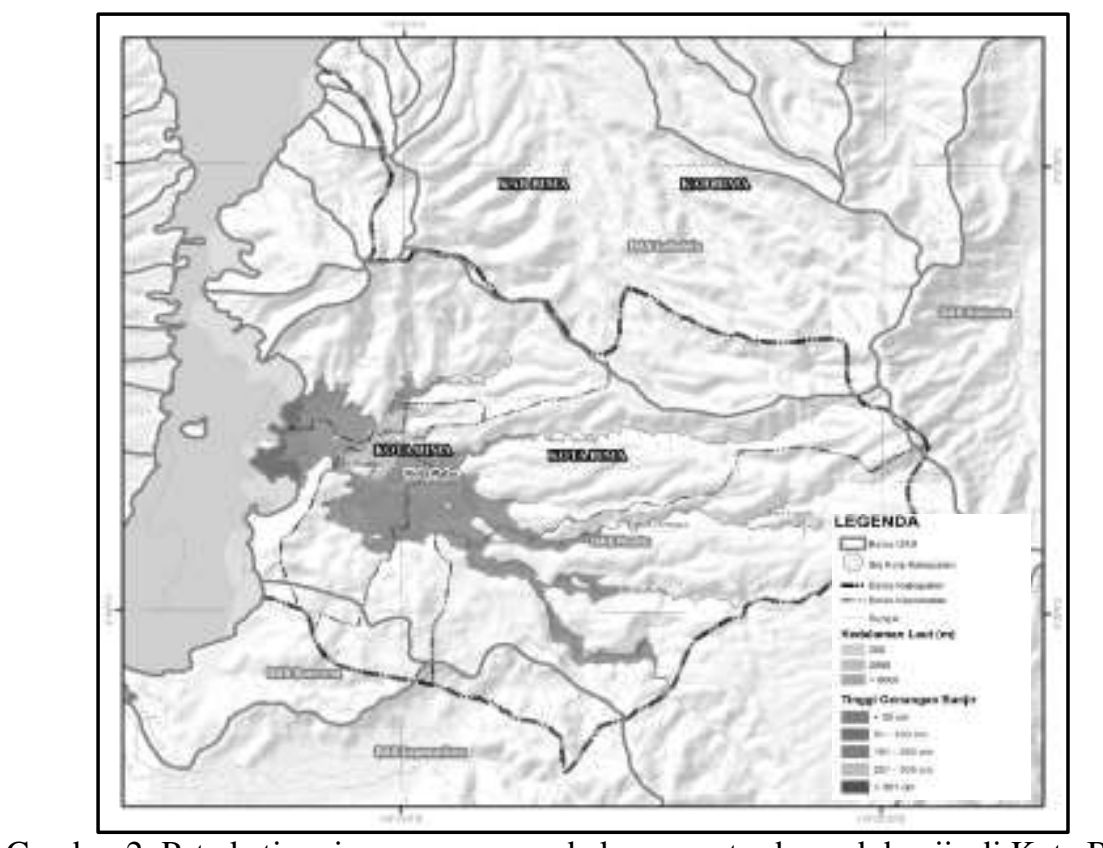

Gambar 2. Peta ketinggian genangan pada kawasan terdampak banjir di Kota Bima Sumber: Hasil Analisis Penulis, 2017

\section{B. Pemodelan Bahaya Banjir}

Pemodelan bahaya banjir dilakukan pada segmen Sungai Melayu dan Sungai Padolo pada DAS Rontu. Dari hasil analisis menunjukkan adanya perbedaan baik luasan yang terdampak secara umum maupun luasan untuk masingmasing kedalaman. Secara signifikan terlihat bahwa pada debit banjir 100 tahunan luas terdampak banjir akan lebih luas dibandingkan dengan luasan wilayah terdampak pada debit banjir 5 tahunan dan debit banjir 25 tahunan, sehingga dalam merumuskan rekomendasi dipilihkan simulasi genangan banjir Q100. Begitupun luasan daerah terdampak pada masing-masing kedalaman yang berbeda sangat jelas terlihat bahwa semakin besar debit banjir yang disimulasikan maka luasan pada masingmasing kedalamanpun semakin luas, dengan kata lain sebagai contoh wilayah yang awalnya terdampak pada kedalaman antara 1 hingga $3 \mathrm{~m}$ pada debit banjir 100 tahunan bisa berubah menjadi wilayah dengan kedalaman banjir lebih dari lebih dari $3 \mathrm{~m}$, seperti pada Gambar 3 . Luasan daerah terdampak banjir Sungai Pedolo dan Sungai Melayu pada simulasi debit Q5, Q25, Q50, dan Q100 dapat dilihat pada Tabel 2 dan Tabel 3.

Tabel 1. Klasifikasi Luasan Daerah Terdampak Banjir Sungai Padolo pada Simulasi Debit Q5, Q25, Q50, dan Q100

\begin{tabular}{llllll}
\hline No & Klasfikasi & \multicolumn{4}{l}{ Luasan, Hektar } \\
& & Q5 & Q25 & Q50 & Q100 \\
\hline 1 & $\leq 1 \mathrm{~m}$ & 72.5 & 78.6 & 81.8 & 85.6 \\
2 & $1 \mathrm{~m}-3 \mathrm{~m}$ & 108.3 & 119.5 & 126.0 & 132.4 \\
3 & $\geq 3 \mathrm{~m}$ & 93.7 & 104.0 & 111.7 & 123.0 \\
& Total & 274.4 & 302.1 & 319.5 & 341.1 \\
\hline
\end{tabular}

Sumber: Kajian Peningkatan Kualitas Tata Ruang Kawasan Rawan Bencana Banjir Banjir Kota Bima, 2017 
Tabel 2. Luasan Daerah Terdampak Banjir Sungai Melayu pada Simulasi Debit Q5, Q25, Q50, dan Q100

\begin{tabular}{llllll}
\hline No & Klasfikasi & \multicolumn{3}{l}{ Luasan, Hektar } & \\
& & Q5 & Q25 & Q50 & Q100 \\
\hline 1 & $\leq 1 \mathrm{~m}$ & 117.2 & 121.2 & 113.5 & 113,5 \\
2 & $1 \mathrm{~m}-3 \mathrm{~m}$ & 51.2 & 59.6 & 76.2 & 82.6 \\
3 & $\geq 3 \mathrm{~m}$ & & 2.2 & 2.2 & 2.4 \\
& Total & 168.3 & 183.0 & 192.0 & 198.5 \\
\hline
\end{tabular}

Sumber: kajian peningkatan kualitas tata ruang kawasan rawan bencana banjir Kota Bima, 2017

\section{Rekomendasi Adaptasi dan Mitigasi dan di Kawasan Rawan Bencana (KRB) \\ Banjir}

Seluruh kawasan Kota Bima menjadi kawasan terdampak banjir berdasarkan histori banjir tahun 2017. Oleh karena itu, perlu upaya adaptasi dan mitigasi bencana di KRB banjir yang termasuk dalam bagian dari manajemen banjir terpadu (Eichhorst, Urda. 2010). Manajemen banjir terpadu merupakan penanganan integral yang mengarahkan semua stakeholder dari manjemen banjir sub sektor ke sektor silang (Kodoatie, 2010). Upaya adaptasi dapat dilakukan pada kawasan terdampak yang terdelineasi sebagai KRB I dan KRB II. Sedangkan perubahan peruntukan ruang dilakukan pada kawasan terdampak yang terdelineasi sebagai KRB III dan juga berada pada dataran banjir (Federal Emergency Management Agency, 2011).

Upaya adaptasi dan mitigasi bencana dan perubahan peruntukan ruang di KRB berdasarkan hasil delineasi ketinggian genangan banjir yang terjadi pada Desember 2016. Berdasarkan hasil pemodelan dan proyeksi ketinggian genangan banjir di masa yang akan datang, kejadian banjir di Kota Bima diprediksi ketinggiannya tidak akan melebihi kejadian bencana banjir pada Desember 2016.

Oleh karena itu, upaya adaptasi dan mitigasi bencana dan perubahan peruntukan ruang ini dapat megacu pada hasil pemodelan dan proyeksi ketinggian bencana banjir, sehingga upaya adaptasi dan mitigasi bencana dan perubahan peruntukan ruang tersebut dapat direkomendasikan hingga jangka panjang. Neuvel dan Van Den Brink (2009) dalam Ran Jing (2016) berpendapat bahwa penataan ruang melalui adaptasi dan mitigasi yang tepat sebagai instrumen untuk mereduksi dampak banjir.

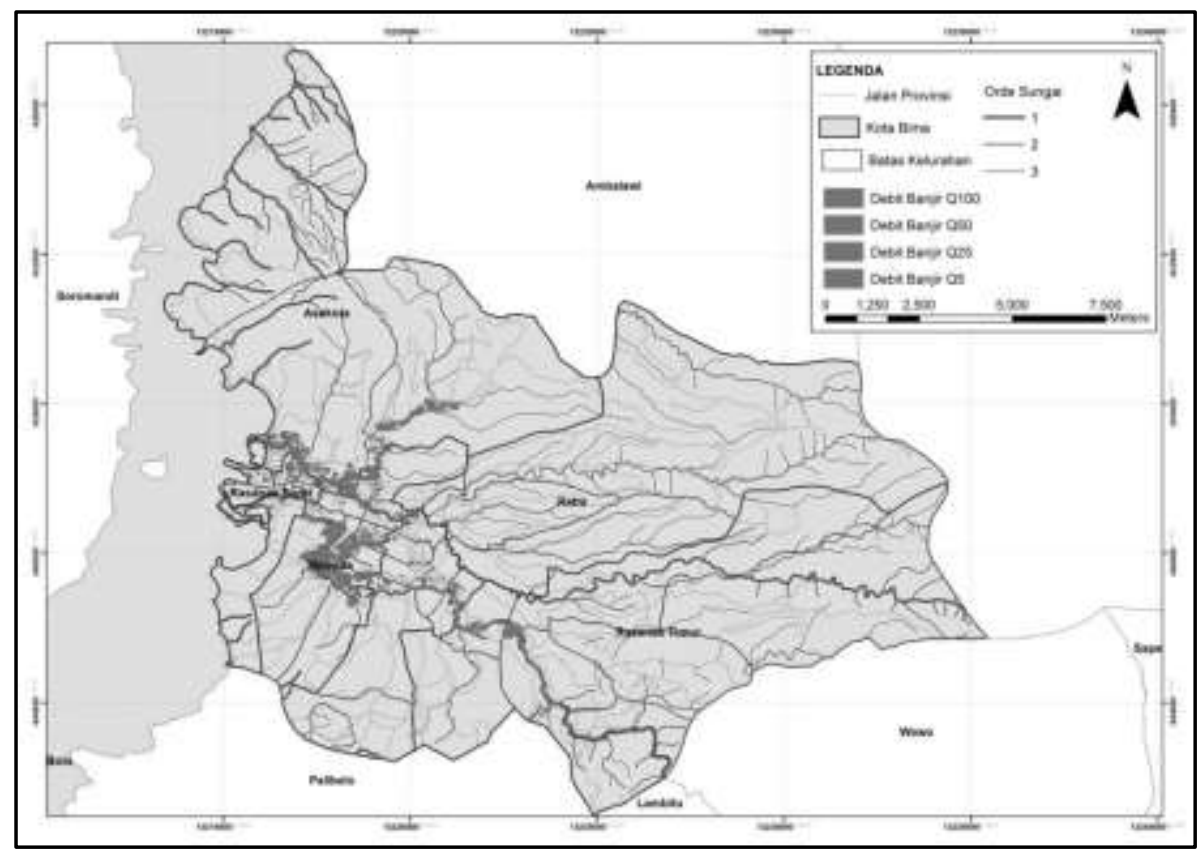

Gambar 3. Visualisasi ketinggian banjir berdasar hasil simulasi

Sumber: Hasil analisis kajian peningkatan kualitas tata ruang kawasan rawan bencana banjir Kota Bima, 2017 
Tabel 3. Luasan wilayah terdampak berdasarkan ketinggian banjir

\begin{tabular}{|c|c|c|c|c|c|}
\hline \multirow[t]{2}{*}{ Kecamatan } & \multirow[t]{2}{*}{ Kelurahan } & \multicolumn{3}{|c|}{ Luas KRB Banjir Q100 (Ha) } & \multirow{2}{*}{$\begin{array}{l}\text { Total } \\
(\mathrm{Ha})\end{array}$} \\
\hline & & $\begin{array}{l}\text { KRB I } \\
(<1 \mathrm{~m})\end{array}$ & $\begin{array}{l}\text { KRB II } \\
(1-3 \mathrm{~m})\end{array}$ & $\begin{array}{l}\text { KRB III } \\
(>3 \mathrm{~m})\end{array}$ & \\
\hline \multirow[t]{3}{*}{ ASAKOTA } & Jatibaru & 19.80 & 14.97 & & 34.77 \\
\hline & Jatiwangi & 32.36 & 30.14 & 0.13 & 62.64 \\
\hline & Melayu & 5.80 & 3.15 & & 8.95 \\
\hline \multirow[t]{10}{*}{ MPUNDA } & Lewirato & 7.85 & 8.18 & 2.99 & 19.03 \\
\hline & Mande & 6.13 & 11.62 & 5.00 & 22.75 \\
\hline & Manggemaci & 2.85 & 6.75 & 8.70 & 18.30 \\
\hline & Matakando & 4.12 & 1.78 & & 5.90 \\
\hline & Monggonao & 3.64 & 1.16 & & 4.80 \\
\hline & Panggi & 7.47 & 14.20 & 9.15 & 30.81 \\
\hline & Penatoi & 12.63 & 3.63 & 0.43 & 16.68 \\
\hline & Sadia & 6.66 & 19.63 & 29.85 & 56.14 \\
\hline & Sambinae & 6.20 & 12.94 & 14.99 & 34.14 \\
\hline & Santi & 10.17 & 22.56 & 2.22 & 34.95 \\
\hline \multirow[t]{7}{*}{ RABA } & Penanae & 0.97 & 1.00 & 0.18 & 2.15 \\
\hline & Penaraga & 3.04 & 3.23 & 0.53 & 6.80 \\
\hline & $\begin{array}{l}\text { Rabadompu } \\
\text { Timur }\end{array}$ & 7.98 & 7.62 & 1.65 & 17.25 \\
\hline & $\begin{array}{l}\text { Rabangodu } \\
\text { Selatan }\end{array}$ & 2.15 & 2.43 & 0.69 & 5.26 \\
\hline & Rabangodu Utara & 2.17 & 2.02 & 0.23 & 4.42 \\
\hline & Rite & 0.45 & 0.46 & 0.00 & 0.91 \\
\hline & Rontu & 3.37 & 3.85 & 1.51 & 8.73 \\
\hline \multirow[t]{6}{*}{ RASANAE BARAT } & Dara & 2.28 & 2.91 & 2.43 & 7.61 \\
\hline & $\mathrm{Nae}$ & 7.14 & 0.32 & & 7.46 \\
\hline & Pane & 2.33 & 1.55 & 0.08 & 3.97 \\
\hline & Paruga & 2.52 & 2.57 & 0.49 & 5.58 \\
\hline & Sarae & 14.12 & 5.73 & & 19.84 \\
\hline & Tanjung & 4.68 & 0.00 & & 4.68 \\
\hline \multirow[t]{4}{*}{ RASANAE TIMUR } & Kodo & 4.47 & 9.63 & 25.66 & 39.76 \\
\hline & Kumbe & 7.73 & 11.79 & 10.79 & 30.31 \\
\hline & Lampe & 6.46 & 6.25 & 4.44 & 17.14 \\
\hline & Oi Fo'o & 1.59 & 2.50 & 3.25 & 7.34 \\
\hline Total Luas $(\mathrm{Ha})$ & & 199.11 & 214.56 & 125.40 & 539.07 \\
\hline
\end{tabular}

Sumber: Hasil analisis penulis, 2017 


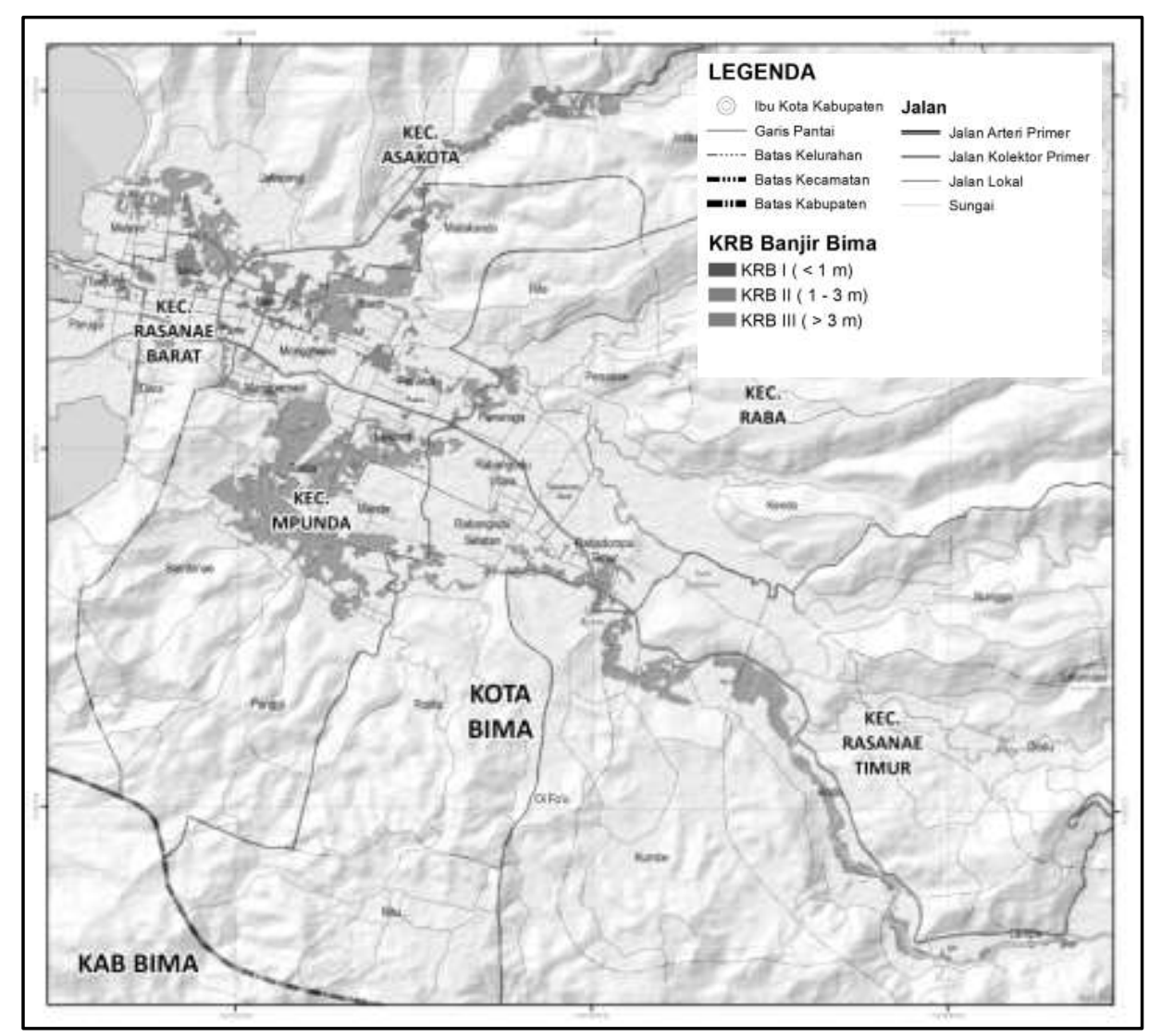

Gambar 4. Peta kawasan rawan banjir di Kota Bima berdasarkan hasil pemodelan banjir pada Q100 Sumber: Hasil analisis penulis, 2017

Wilayah-wilayah yang berada pada KRB I (ketinggian genangan $<1$ meter) dan KRB II (ketinggian genangan 1 hingga 3 meter) memerlukan upaya adaptasi. Upaya adaptasi yang dilakukan melalui pembangunan rumah dan pengembangan sistem jaringan drainase permeabel dan bioretensi. Penggunaan lahan pada KRB III dapat diarahkan untuk menjadi hutan kota, RTH, konservasi tanah dan air, dan daerah resapan air. Tabel 4 menunjukkan luasan wilayah terdampak berdasarkan ketinggian banjir dan Gambar 4 hingga Gambar 6 adalah peta kawasan Rawan Banjir di Kota Bima, Segmen DAS Melayu, dan Segmen DAS Padolo

Wilayah-wilayah yang berada pada KRB tinggi, memerlukan perubahan peruntukan ruang sebagai kawasan lindung KRB banjir dilengkapi dengan ketentuan pemanfaatan ruang yang lebih rinci/floodplain zoning instrument. Upaya mitigasi bencana banjir dapat diwujudkan dalam satu kesatuan DAS Rontu sesuai dengan program-program mitigasi bencana banjir yang telah disepakati lintas Kementerian/Lembaga dan Pemerintah Kota Bima.

Wilayah yang terklasifikasi sebagai KRB I yaitu di Kelurahan Jatibaru, Kelurahan Jatiwangi, dan Kelurahan Melayu (Kecamatan Asakota); Kelurahan Lewirato, Kelurahan Mande, Kelurahan Manggemaci, Kelurahan Matakando, Kelurahan Monggonao, Kelurahan Panggi, Kelurahan Penatoi, Kelurahan Sadia, Kelurahan Sambinae, dan Kelurahan Santi (Kecamatan Mpunda); Kelurahan Penanae, Kelurahan Penaraga, Kelurahan Rabadompu Timur, Kelurahan Rabangodu Selatan, Kelurahan Rabangodu Utara, Kelurahan Rite, dan Kelurahan Rontu (Kecamatan Raba); Kelurahan Dara, Kelurahan Nae, Kelurahan Pane, Kelurahan Paruga, Kelurahan Sarae, dan Kelurahan Tanjung (Kecamatan Rasanae Barat); Kelurahan Kodo, Kelurahan Kumbe, Kelurahan Lampe, dan Kelurahan Oi Fo'o (Kecamatan Rasanae Timur). Upaya adaptasi yang dilakukan pada KRB I adalah kawasan 
budi daya terbangun dengan mendisain sistem jaringan drainase permeabel dan bioretensi dan juga dianjurkan pembangunan kawasan terbangun dengan desain rumah panggung. Selain itu, pada KRB I terdapat upaya mitigasi bencana banjir struktural dan non struktural. Upaya mitigasi bencana struktural antara lain rencana pembangunan sistem pengendali banjir, rencana pembangunan sistem drainase, rencana pembangunan waduk retensi, dan rencana pengembangan sistem peringatan dini. Sedangkan upaya mitigasi bencana non struktural terdiri atas rencana pembangunan dam penahan dan gully plug, rencana pembangunan sumur resapan air, dan konservasi hulu (KLHK, 2017). Tabel 5 adalah upaya adaptasi dan mitigasi bencana di KRB I DAS Rontu.

Tabel 4. Upaya adaptasi dan mitigasi bencana di KRB I

\begin{tabular}{|c|c|c|c|c|}
\hline Kecamatan & Kelurahan & Upaya Adaptasi & $\begin{array}{lr}\text { Upaya } & \text { Mitigasi } \\
\text { Bencana } & \text { Banjir } \\
\text { Struktural } & \\
\end{array}$ & $\begin{array}{l}\text { Upaya Mitigasi } \\
\text { Bencana Banjir Non } \\
\text { Struktural }\end{array}$ \\
\hline Asakota & $\begin{array}{l}\text { Jatibaru } \\
\text { Jatiwangi }\end{array}$ & 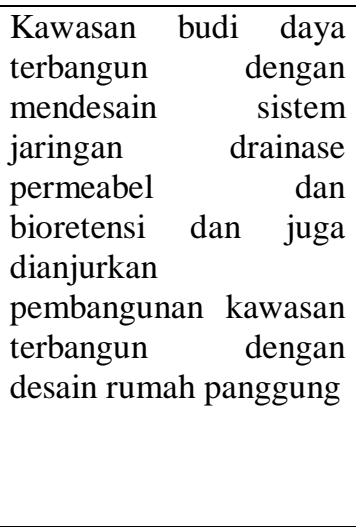 & $\begin{array}{l}\text { Kelurahan Jatibaru: } \\
\text { Rencana pembangunan } \\
\text { sistem pengendali } \\
\text { banjir, sistem drainase, } \\
\text { dan waduk retensi } \\
\text { Kelurahan Jatiwangi: } \\
\text { Rencana pembangunan } \\
\text { sistem pengendali } \\
\text { banjir, sistem drainase, } \\
\text { dan waduk retensi }\end{array}$ & $\begin{array}{l}\text { Kelurahan Jatibaru: } \\
\text { Rencana } \\
\text { pembangunan Dam } \\
\text { Penahan dan Gully } \\
\text { Plug dan juga } \\
\text { konservasi huluDAS } \\
\text { Rontu } \\
\text { Kelurahan Jatiwangi: } \\
\text { Rencana } \\
\text { pembangunan sumur } \\
\text { respan air dan } \\
\text { konervasi hulu DAS } \\
\text { Rontu }\end{array}$ \\
\hline Rasanae Timur & $\begin{array}{l}\text { Dodu } \\
\text { Kodo } \\
\text { Lampe } \\
\text { Nungga }\end{array}$ & & $\begin{array}{l}\text { Kelurahan Dodu: } \\
\text { Rencana pembangunan } \\
\text { sistem pengendali } \\
\text { banjir, sistem drainase, } \\
\text { dan waduk retensi } \\
\text { Kelurahan Kodo: } \\
\text { Rencana pembangunan } \\
\text { sistem pengendali } \\
\text { banjir dan sistem } \\
\text { drainase } \\
\text { Kelurahan Lampe: } \\
\text { Rencana pembangunan } \\
\text { sistem pengendali } \\
\text { banjir, sistem drainase, } \\
\text { waduk retensi, dan } \\
\text { sistem peringatan dini } \\
\text { Kelurahan Nungga: } \\
\text { Rencana pembangunan } \\
\text { sistem pengendali } \\
\text { banjir, sistem drainase, } \\
\text { dan sistem peringatan } \\
\text { dini }\end{array}$ & $\begin{array}{lr}\text { Kelurahan } & \text { Dodu } \\
\text { dan Keurahan } & \text { Kencana } \\
\text { Nungga: Ren } & \text { Rembangunan Dam } \\
\text { pemban } & \text { Penahan dan } \text { Gully } \\
\text { Plug } & \\
\text { Kelurahan Kodo: } \\
\text { Rencana } \\
\text { pembangunan sumber } \\
\text { resapan air }\end{array}$ \\
\hline
\end{tabular}

Sumber: Hasil analisis penulis, 2017 
Wilayah yang terklasifikasi sebagai KRB II yaitu di Kelurahan Jatibaru, Kelurahan Jatiwangi, dan Kelurahan Melayu (Kecamatan Asakota); Kelurahan Lewirato, Kelurahan Mande, Kelurahan Manggemaci, Kelurahan Matakando, Kelurahan Monggonao, Kelurahan Panggi, Kelurahan Penatoi, Kelurahan Sadia, Kelurahan Sambinae, dan Kelurahan Santi (Kecamatan Mpunda); Kelurahan Penanae, Kelurahan Penaraga, Kelurahan Rabadompu
Timur, Kelurahan Rabangodu Selatan, Kelurahan Rabangodu Utara, Kelurahan Rite, dan Kelurahan Rontu (Kecamatan Raba); Kelurahan Dara, Kelurahan Nae, Kelurahan Pane, Kelurahan Paruga, Kelurahan Sarae, Kelurahan Tanjung (Kecamatan Rasanae Barat), Kelurahan Kodo, Kelurahan Kumbe, Kelurahan Lampe, dan Kelurahan Oi Fo'o (Kecamatan Rasanae Timur).

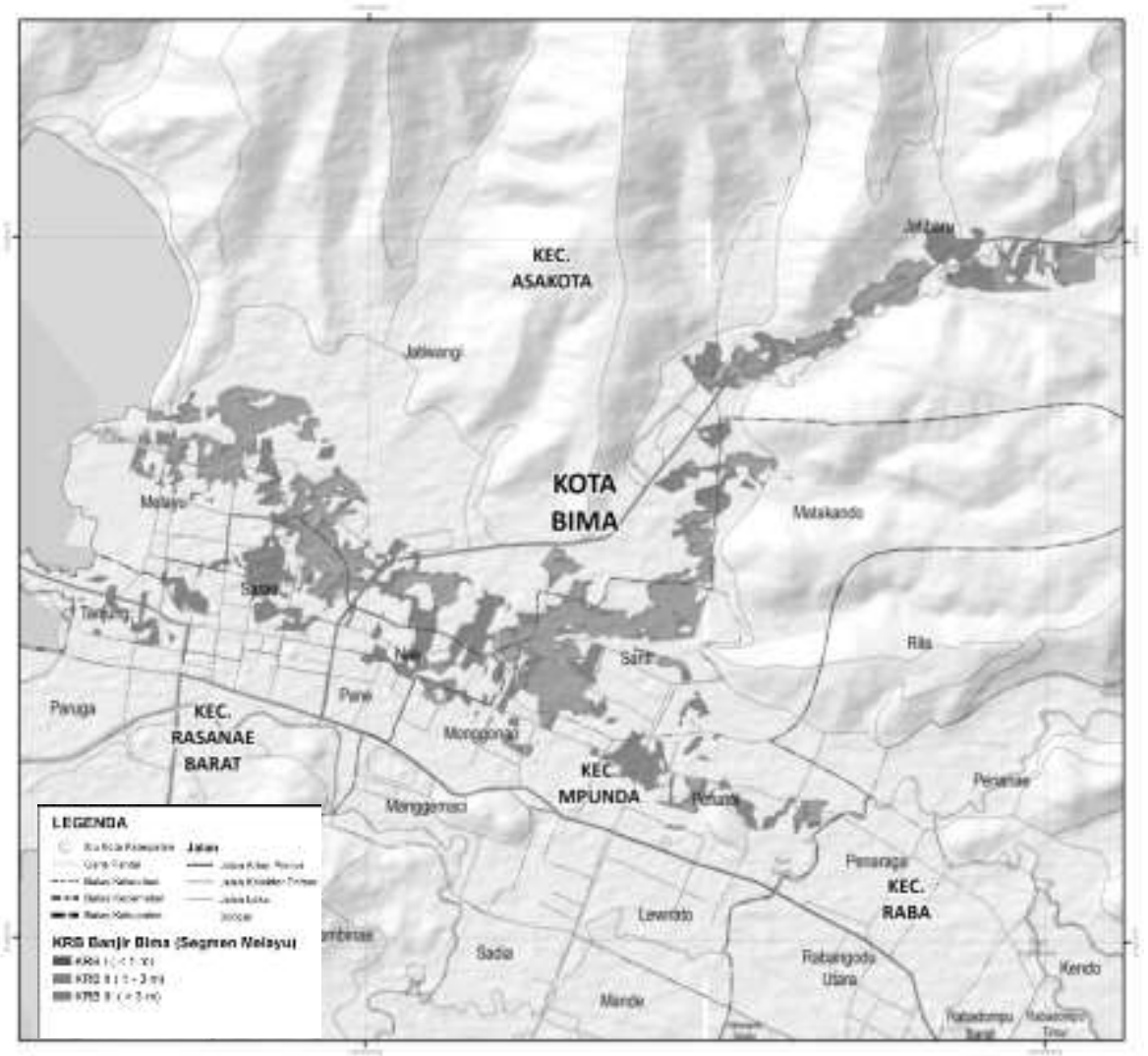

Gambar 5. Peta kawasan rawan banjir di Kota Bima berdasarkan hasil pemodelan banjir pada Q100 di segmen DAS Melayu

Sumber: Hasil analisis penulis, 2017

Upaya adaptasi yang dilakukan pada KRB II adalah kawasan budi daya terbangun dengan mendesain sistem jaringan drainase permeabel dan bioretensi dan juga diwajibkan pembangunan kawasan terbangun dengan desain rumah panggung. Selain itu, pada KRB II terdapat upaya mitigasi bencana banjir struktural dan non struktural.

Upaya mitigasi bencana struktural antara lain rencana pembangunan sistem pengendali banjir, rencana pembangunan sistem drainase, rencana pembangunan waduk retensi, rencana pengembangan sistem peringatan dini, dan rencana pembangunan jetty pada muara sungai. Sedangkan, upaya mitigasi bencana non struktural terdiri atas rencana pembangunan Dam Penahan dan gully plug, rencana pembangunan sumur resapan air, dan konservasi hulu. Tabel 6 adalah upaya adaptasi dan mitigasi bencana di KRB II DAS Rontu. 
Tabel 5. Upaya adaptasi dan mitigasi bencana di KRB II

\begin{tabular}{|c|c|c|c|c|}
\hline Kecamatan & Kelurahan & Upaya Adaptasi & $\begin{array}{l}\text { Upaya Mitigasi } \quad \text { Bencana } \\
\text { Struktural }\end{array}$ & $\begin{array}{lr}\text { Upaya } & \text { Mitigasi } \\
\text { Bencana } & \text { Non } \\
\text { Struktural } & \end{array}$ \\
\hline Asakota & $\begin{array}{l}\text { Jatibaru } \\
\text { Jatiwangi } \\
\text { Melayu }\end{array}$ & \multirow[t]{5}{*}{$\begin{array}{l}\text { Kawasan budi daya } \\
\text { terbangun dengan } \\
\text { mendesain sistem } \\
\text { jaringan drainase } \\
\text { permeabel dan } \\
\text { bioretensi dan juga } \\
\text { diwajibkan } \\
\text { pembangunan } \\
\text { kawasan terbangun } \\
\text { dengan desain } \\
\text { rumah panggung }\end{array}$} & $\begin{array}{lr}\text { Kelurahan Jatibaru, } & \text { Kelurahan } \\
\text { Jatiwangi: } & \text { Rencana } \\
\text { pembangunan } & \text { sistem } \\
\text { pengendali banjir, } & \text { sistem } \\
\text { drainase, waduk retensi } & \\
\text { Kelurahan Melayu: } & \text { Rencana } \\
\text { pembangunan } & \text { sistem } \\
\text { pengendali banjir, } & \text { sistem } \\
\text { drainase, jetty } & \end{array}$ & $\begin{array}{l}\text { Rencana } \\
\text { pembangunan Dam } \\
\text { Penahan dan Gully } \\
\text { Plug } \\
\text { Konservasi hulu DAS } \\
\text { Rontu } \\
\text { Rencana } \\
\text { pembangunan sumur } \\
\text { resapan air, } \\
\text { Konservasi hulu DAS } \\
\text { Rontu }\end{array}$ \\
\hline Mpunda & $\begin{array}{l}\text { Lewirato } \\
\text { Mande } \\
\text { Manggemaci } \\
\text { Monggonao } \\
\text { Panggi } \\
\text { Penatoi } \\
\text { Sadia } \\
\text { Sambinae } \\
\text { Santi } \\
\end{array}$ & & $\begin{array}{l}\text { Rencana pembangunan sistem } \\
\text { pengendali banjir dan sistem } \\
\text { drainase }\end{array}$ & - \\
\hline Raba & $\begin{array}{l}\text { Kendo } \\
\text { Ntobo } \\
\text { Penanae } \\
\text { Rabadompu Barat } \\
\text { Rabadompu Timur } \\
\text { Rabangodu Selatan } \\
\text { Rabangodu Utara } \\
\text { Rite } \\
\text { Rontu }\end{array}$ & & $\begin{array}{lr}\text { Seluruh } & \text { kelurahan } \\
\text { Kecamatan Raba: } & \text { Rencana } \\
\text { pembangunan } & \text { sistem } \\
\text { pengendali banjir dan drainase } \\
\text { Kelurahan } & \text { Penaraga: } \\
\text { pembangunan } & \text { sistem } \\
\text { pengendali banjir, drainase, dan } & \\
\text { waduk retensi } & \end{array}$ & $\begin{array}{l}\text { Kelurahan } \\
\text { Rabadompu Barat, } \\
\text { Rabadompu Timur, } \\
\text { dan Rabangodu } \\
\begin{array}{l}\text { Selatan: Rencana } \\
\text { pembangunan sumur } \\
\text { resapan air }\end{array}\end{array}$ \\
\hline $\begin{array}{l}\text { Rasanae } \\
\text { Barat }\end{array}$ & $\begin{array}{l}\text { Dara } \\
\text { Nae } \\
\text { Pane } \\
\text { Paruga } \\
\text { Sarae } \\
\text { Tanjung }\end{array}$ & & $\begin{array}{l}\text { Kelurahan Dara, Keluahan Nae, } \\
\text { Kelurahan Pane, Kelurahan } \\
\text { Sarae: Rencana pembangunan } \\
\text { sistem pengendali banjir dan } \\
\text { drainase } \\
\text { Kelurahan Paruga dan } \\
\text { Kelurahan Tanjung: Rencana } \\
\text { pembangunan sistem } \\
\text { pengendali banjir, drainase, dan } \\
\text { jetty }\end{array}$ & - \\
\hline $\begin{array}{l}\text { Rasanae } \\
\text { Timur }\end{array}$ & $\begin{array}{l}\text { Dodu } \\
\text { Kodo } \\
\text { Kumbe } \\
\text { Lampe } \\
\text { Nungga }\end{array}$ & & 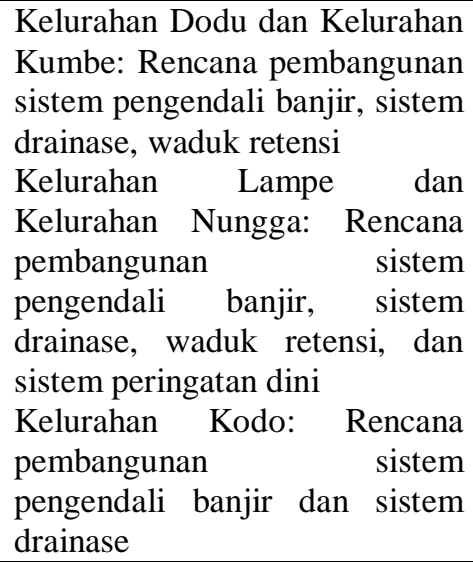 & $\begin{array}{l}\text { Kelurahan Dodu dan } \\
\text { Kelurahan Nungga: } \\
\text { Rencana } \\
\text { pembangunan } \\
\begin{array}{l}\text { Penahan dan } \\
\text { Plug }\end{array} \\
\begin{array}{l}\text { Kelurahan } \\
\text { Rencana } \\
\text { pembangunan }\end{array} \\
\begin{array}{l}\text { Kesapan air } \\
\text { resamur }\end{array}\end{array}$ \\
\hline
\end{tabular}

Sumber: Hasil analisis penulis, 2017 
Wilayah yang terklasifikasi sebagai KRB III yaitu Kelurahan Jatiwangi (Kecamatan Asakota); Kelurahan Lewirato, Kelurahan Mande, Kelurahan Manggemaci, Kelurahan Panggi, Kelurahan Penatoi, Kelurahan Sadia, Kelurahan Sambinae, dan Kelurahan Santi (Kecamatan Mpunda); Kelurahan Penanae, Kelurahan Penaraga, Kelurahan Rabadompu Timur, Kelurahan Rabangodu Selatan, Kelurahan Rabangodu Utara, Kelurahan Rite, dan Kelurahan Rontu (Kecamatan Raba); Kelurahan Dara, Kelurahan Pane, dan Kelurahan Paruga (Kecamatan Rasanae Barat), Kelurahan Kodo, Kelurahan Kumbe, Kelurahan Lampe, dan Kelurahan Oi Fo'o (Kecamatan Rasanae Timur).
Perubahan peruntukan ruang dilakukan pada KRB III, sehingga masyarakat yang tinggal di KRB III perlu direlokasi. Pada KRB III terdapat upaya mitigasi bencana banjir struktural dan non struktural. Upaya mitigasi bencana struktural antara lain rencana pembangunan sistem pengendali banjir, rencana pembangunan sistem drainase, dan rencana pembangunan waduk retensi. Sedangkan, upaya mitigasi bencana non struktural terdiri atas rencana pembangunan Dam Penahan dan gully plug, rencana pembangunan sumur resapan air, dan konservasi hulu. Tabel 7 adalah upaya adaptasi dan mitigasi bencana di KRB III DAS Rontu.

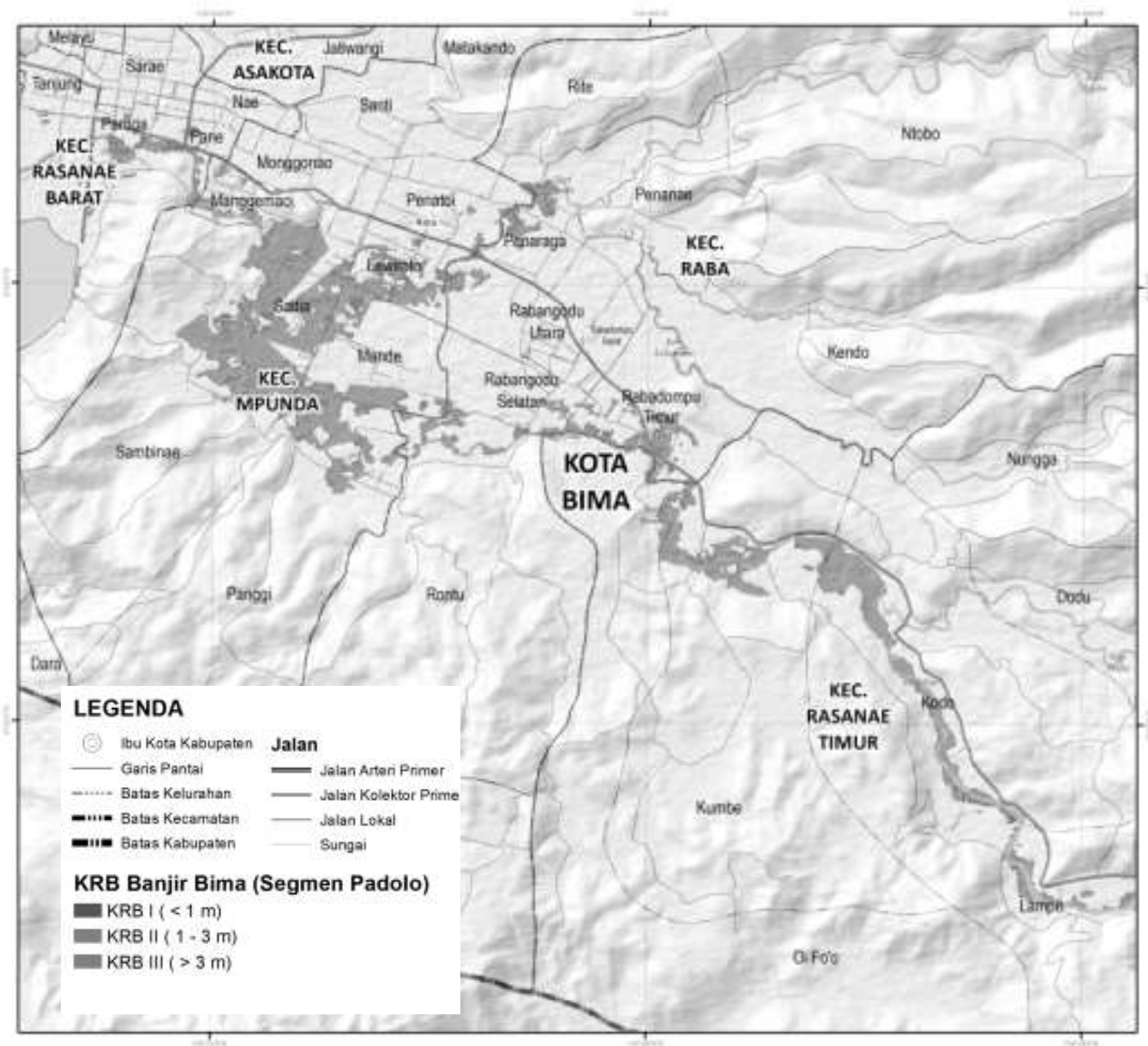

Gambar 6. Peta kawasan rawan banjir di Kota Bima berdasarkan hasil pemodelan banjir pada Q100 di segmen DAS Padolo

Sumber: Hasil analisis penulis, 2017 
Tabel 6. Upaya adaptasi dan mitigasi bencana di KRB III

\begin{tabular}{|c|c|c|c|c|}
\hline Kecamatan & Kelurahan & $\begin{array}{l}\text { Perubahan } \\
\text { Peruntukan Ruang }\end{array}$ & $\begin{array}{l}\text { Upaya Mitigasi } \\
\text { Bencana Struktural }\end{array}$ & $\begin{array}{l}\text { Upaya Mitigasi Bencana } \\
\text { Non Struktural }\end{array}$ \\
\hline Asakota & $\begin{array}{l}\text { Jatibaru } \\
\text { Jatiwangi }\end{array}$ & $\begin{array}{lr}\text { Kawasan rawan } & \text { rawjir } \\
\text { bencana } & \text { banjir } \\
\text { sebagai kawasan } & \text { kaing } \\
\text { lindung KRB banjir } \\
\text { dilengkapi dengan } \\
\text { ketentuan } \\
\text { pemanfaatan ruang } \\
\text { yang lebih } \\
\text { rinci/floodplain } \\
\text { zoning instrument }\end{array}$ & $\begin{array}{l}\text { Seluruh kelurahan di } \\
\text { Kecamatan Asakota: } \\
\text { Rencana pembangunan } \\
\text { sistem pengendali } \\
\text { banjir, sistem drainase, } \\
\text { dan waduk retensi }\end{array}$ & $\begin{array}{l}\text { Kelurahan Jatibaru: } \\
\text { Rencana pembangunan } \\
\text { Dam Penahan dan Gully } \\
\text { Plug dan konservasi } \\
\text { hulu DAS Rontu } \\
\text { Kelurahan Jatiwangi: } \\
\text { Rencana pembangunan } \\
\text { sumur resapan air dan } \\
\text { konservasi hulu DAS } \\
\text { Rontu }\end{array}$ \\
\hline Mpunda & $\begin{array}{l}\text { Lewirato } \\
\text { Manggemaci } \\
\text { Matakando } \\
\text { Monggonao } \\
\text { Penatoi } \\
\text { Sadia } \\
\text { Santi }\end{array}$ & & $\begin{array}{l}\text { Seluruh kelurahan di } \\
\text { Kecamatan Mpunda: } \\
\text { Rencana pembangunan } \\
\text { sistem pengendali } \\
\text { banjir dan sistem } \\
\text { drainase }\end{array}$ & - \\
\hline Raba & $\begin{array}{l}\text { Penaraga } \\
\text { Rabadompu } \\
\text { Timur }\end{array}$ & & $\begin{array}{l}\text { Kelurahan Penaraga: } \\
\text { Rencana pembangunan } \\
\text { sistem pengendali } \\
\text { banjir, sistem drainase, } \\
\text { dan waduk retensi } \\
\text { Kelurahan Rabadompu } \\
\text { Timur: Rencana } \\
\text { pembangunan sistem } \\
\text { pengendali banjir dan } \\
\text { sistem drainase }\end{array}$ & $\begin{array}{lr}\text { Kelurahan } & \text { Rabadompu } \\
\text { Timur: } & \text { Rencana } \\
\text { pembangunan } & \text { sumur } \\
\text { resapan air } & \end{array}$ \\
\hline $\begin{array}{l}\text { Rasanae } \\
\text { Barat }\end{array}$ & $\begin{array}{l}\text { Nae } \\
\text { Pane }\end{array}$ & & $\begin{array}{l}\text { Kelurahan Nae dan } \\
\text { Kelurahan } \\
\text { Rencana pembangunan } \\
\text { sistem } \\
\text { banjir dan pengendali } \\
\text { drainase }\end{array}$ & - \\
\hline
\end{tabular}

Sumber: Hasil analisis penulis, 2017

\section{KESIMPULAN DAN REKOMENDASI}

Berdasarkan pemetaan kawasan terdampak dan pemodelan bahaya banjir, maka dapat ditentukan rekomendasi alternatif pemanfaatan lahan berbasis Pengurangan Risiko Bencana, yaitu adaptasi, mitigasi, dan perubahan peruntukan ruang. Upaya adaptasi dan mitigasi dapat dilakukan pada KRB I dan KRB II. Sedangkan perubahan peruntukan ruang dilakukan pada KRB III. Upaya adaptasi, mitigasi dan perubahan peruntukan ruang merupakan bagian dari perwujudan penataan ruang berbasis Pengurangan Risiko Bencana. Pemanfaatan lahan di KRB banjir sebaiknya mempertimbangkan tingkat kerawanan bencana. Berdasarkan tingkat kerawanan bencana maka dapat ditentukan rekomendasi alternatif pemanfaatan lahan berbasis Pengurangan Risiko Bencana, yaitu adaptasi, mitigasi, dan perubahan peruntukan ruang. Upaya adaptasi dan mitigasi dapat dilakukan pada KRB I dan KRB II. Sedangkan perubahan peruntukan ruang dilakukan pada KRB III. Upaya adaptasi, mitigasi dan perubahan peruntukan ruang merupakan bagian dari perwujudan penataan ruang berbasis Pengurangan Risiko Bencana. 


\section{UCAPAN TERIMA KASIH}

Penulis ucapkan terima kasih kepada Kementerian Agraria dan Tata Ruang/BPN yang telah memberikan kesempatan kepada penulis untuk berkontribusi pada kegiatan Peningkatan Kualitas Tata Ruang Kawasan Rawan Bencana (KRB) Banjir di Kota Bima. Hasil dari kegiatan tersebut menjadi acuan dalam kajian "Rekomendasi Adaptasi dan Mitigasi di Kawasan Rawan Bencana (KRB) Banjir Kota Bima".

\section{DAFTAR PUSTAKA}

Arsjad, A. B. S. M. \& Riadi, B. (2013). Potensi Risiko Bencna Alam Longsor terkait Cuaca Ekstrim di Kabupaten Ciamis, Jawa Barat. Jurnal Ilmiah Geomatika, 19 (1), 57-63.

Badan Meteorologi, Klimatologi, dan Geofisika. (2016). Buletin Pemantauan Ketahanan Pangan Indonesia, Fokus Utama Cuaca Ekstrim. Jakarta: BMKG

Eichhorst, U. (2010). Climate-Proof Urban Transport Planning: Opprtunities and Challenges in Developing Cities. Proceding of Global Forum 2010. New York: Spinger; London: Dordrecht Heidelberg.

Federal Emergency Management Agency. (2011). Flood Zones, Federal Emergency Management Agency (FEMA). U.S. Department of Homeland

Kementerian Agraria dan Tata Ruang/BPN. (2017). Peningkatan Kualitas Tata Ruang Kawasan Rawan Bencana Banjir Kota Bima (tidak terpublikasi).

Kementerian Lingkungan Hidup dan Kehutanan. (2017). Mitigasi Banjir DAS Sari melalui Rehabilitasi Hutan dan Lahan (tidak terpublikasi).

Kodoatie, R. J. \& Sjarief, R. (2010). Tata Ruang Air. Andi Offset: Yogyakarta
Peraturan Pemerintah Nomor 21 Tahun 2008 tentang Penyelenggaraan Penanggulangan Bencana.

Peraturan Pemerintah Nomor 26 Tahun 2008 tentang Rencana Tata Ruang Wilayah Nasional (RTRWN).

Peraturan Pemerintah Nomor 15 Tahun 2010 tentang Penyelenggaraan Penataan Ruang.

Peraturan Daerah Provinsi Nusa Tenggara Barat Nomor 3 Tahun 2010 tentang Rencana Tata Ruang Wilayah Provinsi Nusa Tenggara Barat Tahun 2009-2029.

Peraturan Daerah Kota Bima Nomor 4 Tahun 2012 tentang Rencana Tata Ruang Wilayah Kota Bima Tahun 20112031.

Ran, J. \& Zorica, N. (2014). Integrating Spatial Planning and Flood Risk Management: A New Conceptual Framework for The Spatially Integrated Policy Infrastructure. Computers, Environment and Urban Systems, 57 (2016) 68-79.

Santosa, P. B. (2006). The Role of GIS For Flood Disaster Management. Makalah pada Pertemuan Ilmiah Tahunan III. Teknik Geomatika Institut Teknologi Sepuluh November. Surabaya

Seniarwan, Baskoro, D. P. T., \& Gandasasmita, K. (2013). Model Spasial Genangan Banjir: Studi Kasus Wilayah Sungai Mangottong, Kabupaten Sinjai, Provinsi Sulawesi Selatan. Globe, 15 (1), 62-67.

Soemabrata, J., Zubair, A., Sondang, I. \& Suyanti, E. (2018). Risk Mapping Studies of Hydro-Meteorological Hazard in Depok Middle City. International Journal of GEOMATE, 14 (44), 128-133.

The Office of Public Works Environment, Heritage, and Local Government and Public Works of Ireland. (2009). The Planning System and Flood Risk Management: Guidelines for Planning Authorities 
Yanto, Livneh, B., Rajagopalan, B., \& Kasprzyk, J. (2017). Hydrological Model Application Under Data Scarcity for Multiple Watersheds, Java Island, Indonesia. Journal of Hydrology: Regional Studies, 9 (Ferbruary 2017) 127-139.

Undang-Undang Nomor 24 Tahun 2007 tentang Penanggulangan Bencana.

Undang-Undang Nomor 26 Tahun 2007 tentang Penataan Ruang.

http://dibi.bnpb.go.id/data-bencana http://www.unisdr.org 